\title{
Chemical Reaction and Crystalline Procedure of Bismuth Titanate Nanoparticles Derived by Metalorganic Decomposition Technique
}

\author{
Weiliang Liu ${ }^{1 *}$, Xinqiang Wang ${ }^{2}$, Dong Tian ${ }^{1}$, Chenglong Xiao ${ }^{1}$, Zengjiang Wei ${ }^{1}$, Shouhua Chen ${ }^{1}$ \\ ${ }^{1}$ Provincial Key Laboratory of Glass and Ceramics, School of Materials Science and Engineering, Shandong Institute of Light Indus- \\ try, Jinan, China; ${ }^{2}$ State Key Laboratory of Crystal Materials, Shandong University, Jinan, China. \\ Email: wlliu@sdu.edu.cn; liuwl@sdili.edu.cn
}

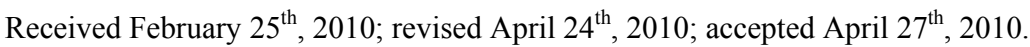

\begin{abstract}
The homogeneous bismuth titanate single-phase nanoscaled ceramic powders have been prepared by means of metalorganic decomposition. The thermal decomposition/oxidation of the pre-heated precursor, as investigated by differential thermalgravimetric analysis, X-ray powder diffraction, and environment scanning electron microscope, lead to the formation of a well-defined orthorhombic bismuth titanate compound. Formation of the layered perovskite-like bismuth titanate occurs via intermediates with sequential changes in the coordination polyhedron of bismuth. The chemical reactions of precursor powder in heat treatment process have been investigated further by Raman and Fourier transform infrared spectra, and the reaction mechanism was tentatively proposed thereafter.
\end{abstract}

Keywords: Reaction Mechanism, Metalorganic Decomposition, Bismuth Titanate, Nanopowders

\section{Introduction}

Bismuth titanate $\left(\mathrm{Bi}_{4} \mathrm{Ti}_{3} \mathrm{O}_{12}\right.$, BTO) belongs to the family of ferroelectric materials with layered structures, which can be written as a general formula of $\left(\mathrm{Bi}_{2} \mathrm{O}_{2}\right)^{2+}\left(\mathrm{Bi}_{2}\right.$ $\left.\mathrm{Ti}_{3} \mathrm{O}_{10}\right)^{2-}$. The layered structure is constructed by alternative stacking of a triple layer of $\mathrm{TiO}_{6}$ octahedra (perovskite slab) and a monolayer of $\left(\mathrm{Bi}_{2} \mathrm{O}_{2}\right)^{2+}$ along the $c$-axis. Single crystal BTO has low dielectric permittivity and a very high Curie temperature $\left(T_{c}=675^{\circ} \mathrm{C}\right)$, which makes it useful for various applications such as memory elements, optical displays, and piezoelectric converters of pyroelectric devices in a wide temperature range from 20 to $600^{\circ} \mathrm{C}$. BTO ceramics have been used in capacitors, transducers, sensors, etc. [1,2]. The tuning of electric properties by compositional modification as well as the size effect can meet commercial specifications for Curie temperature, conductivity, coercivity, compliance, etc. $[3,4]$.

Although BTO is normally prepared by solid-state reaction of $\mathrm{Bi}_{2} \mathrm{O}_{3}$ and $\mathrm{TiO}_{2}$ at elevated temperatures up to $1100^{\circ} \mathrm{C}$ [5], owing to some inherent limitations of the process that yields large grain size of product phase, several alternate chemical syntheses routes have been proposed. These include coprecipitation, sol-gel, hydrothermal and molten salt synthesis [6-9]. Metalorganic decomposition (MOD) employed in the study offers the advantages of low calcining temperature, simplifying process, better homogeneity, stoichiometric composition control, and low cost. The formation mechanism of the BTO prepared using MOD method, therefore, was proposed in order to get better understanding of the reaction process.

\section{Experimental}

The required amounts of bismuth nitrate $\left[\mathrm{Bi}\left(\mathrm{NO}_{3}\right)_{3} \cdot 5 \mathrm{H}_{2} \mathrm{O}\right]$ was dissolved in glacial acetic acid $\left(\mathrm{CH}_{3} \mathrm{COOH}\right)$ by stirring at $60^{\circ} \mathrm{C}$ up to achieve complete dissolution. Stoichiometric tetrabutyl titanate $\left[\mathrm{Ti}\left(\mathrm{OC}_{4} \mathrm{H}_{9}\right)_{4}\right]$ was slowly $\mathrm{dr}$ opped into the above solution under constant rate stirring. Acetylacetone $\left(\mathrm{CH}_{3} \mathrm{COCH}_{2} \mathrm{COCH}_{3}\right)$ as reagent was used to stabilize tetrabutyl titanate. And the solution was diluted with 2-methoxyethanol $\left(\mathrm{CH}_{3} \mathrm{OCH}_{2} \mathrm{CH}_{2} \mathrm{OH}\right)$ to adjust viscosity and surface tension. The resultant solution was stirred at room temperature for $1 \mathrm{~h}$ and filtered whereafter to form the stock solution, which was yellow, clear, and transparent.

The precursor solution thus obtained was dried in an oven at $90^{\circ} \mathrm{C}$ for $10 \mathrm{~h}$, resulting in the formation of a fine yellowish powder. After ground in an agate, the powder was annealed at various temperatures between 450 and $750^{\circ} \mathrm{C}$. Thermal reactions taking place during the calci- 
nations of the powder were analyzed in air by thermogravimetric and differential thermal analysis (TG/DTA, Netzsch STA 449c). The existing phases in the calcined samples were studied by X-Ray diffraction (XRD, Rigaku D/MAX- $\gamma \mathrm{A}$ ). Crystallite size of calcined powders was determined by X-ray line broadening using the Scherrer equation [10]. The evolution of the powder morphology with the calcination temperature was studied by an environment scanning electron microscope (ESEM, Quanta 200). The Raman measurements were performed in the backscattering geometry using a Ventuno 21 NRS1000DT instrument at room temperature to study the lattice dynamics and structural variety. The infrared (IR) spectra were measured from $400-4000 \mathrm{~cm}^{-1}$ with a Bruker Tensor 27 FT-IR spectrometer to monitor the chemical reaction.

\section{Results and Discussion}

\subsection{Thermal Analysis}

The relative weight loss (44\%) and differential thermal analysis of the pre-heated precursor, as shown in Figure 1, indicate that heat begins to evolve at about $300^{\circ} \mathrm{C}$ and the second weight loss occurs around $600^{\circ} \mathrm{C}$. It is seen from the curve of the DTA in this figure that two exothermic effects appear at about 350 and $750^{\circ} \mathrm{C}$, respectively. Combined with TGA data, it is obvious that the endothermic effect at about $350^{\circ} \mathrm{C}$ is due to the decomposition and decarbonization of organic and inorganic compounds. It also demonstrates that the weight loss takes place in the endothermic processing between 270 and $420^{\circ} \mathrm{C}$, which is about $24 \%$. The DTA curve shows the exothermic effect at about $350^{\circ} \mathrm{C}$, which probably also corresponds to the first nucleation events and the solid-state reaction, and it will be discussed in XRD data. With an increase in temperature, the second exothermic effect, which appears to be located at $\sim 750^{\circ} \mathrm{C}$ is also present. Although no previous thermodynamic data have been found in the literature, the second exothermic effect may be attributed to the formation of small agglomerate of pure BTO ceramic powders, and the crystallization process of BTO is completed before $750^{\circ} \mathrm{C}$. At that temperature the weight loss is finished. The crystallization process takes place simultaneously with the combustion of residual organic products and/or carbon.

\subsection{XRD Study}

Diffraction is an appropriate technique when following the formation of a crystalline solid to obtain qualitative information about the course of a reaction and phase identification at each step. This information is the first step in being able to postulate reaction mechanisms.

The X-ray diffraction studies on the samples calcined at different temperatures for $5 \mathrm{~min}$ are shown in Figure 2.

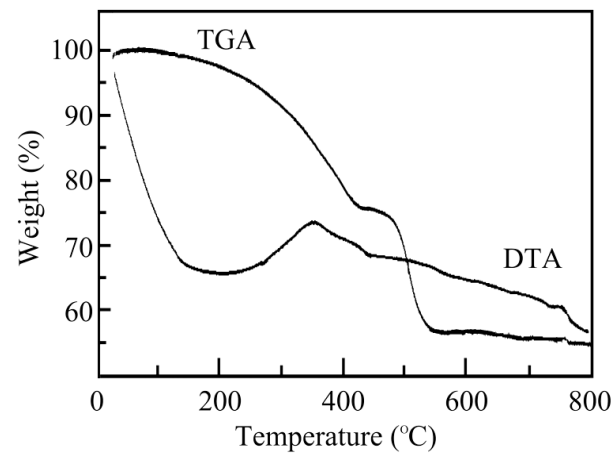

Figure 1. TG/DTA curves for stock precursors

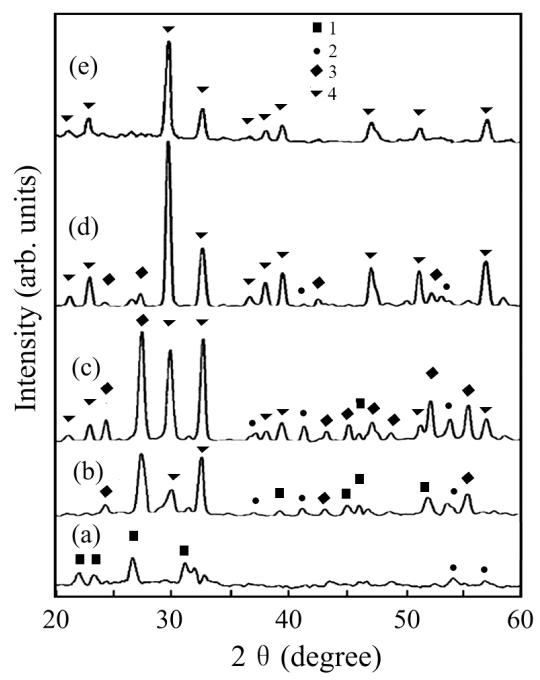

Figure 2. X-ray diffraction patterns of BTO precursor calcined at various temperatures of 90 (a), 450 (b), 550 (c), 650 (d), and $750^{\circ} \mathrm{C}$ (e). Peaks: (1) Bi2O3, (2) TiO2, (3) Bi12TiO20, and (4) Bi4Ti3O12

The XRD pattern of initial powder confirms the amortphous nature, indicating that the powder is non-crystalline. The precursor shows evident crystallization as the emperatures increases to $450^{\circ} \mathrm{C}$, and the three strong peaks correspond to $\mathrm{Bi}_{12} \mathrm{TiO}_{20}$ and $\mathrm{Bi}_{4} \mathrm{Ti}_{3} \mathrm{O}_{12}$, respectively. In the short temperature interval of $450-550^{\circ} \mathrm{C}$ the precursor converts completely into the bismuth titanate compound (BTO and $\mathrm{Bi}_{12} \mathrm{TiO}_{20}$ ). Between 550 and $750^{\circ} \mathrm{C}$ all the amorphous phases react rapidly with the $\mathrm{Bi}_{12} \mathrm{TiO}_{20}$ intermediate phase leading to the formation of the BTO compound. It is also found from the XRD spectra that BTO powder has orthorhombic phase structure when the annealing temperature is $750^{\circ} \mathrm{C}$. The crystallite sizes of the powder heated at $750^{\circ} \mathrm{C}$ for $5 \mathrm{~min}$ are determined to be $\sim 40 \mathrm{~nm}$ from the half-width of the X-ray diffraction peaks using Scherrer's equation.

$$
t=\frac{k \lambda}{\beta \cos \theta},
$$




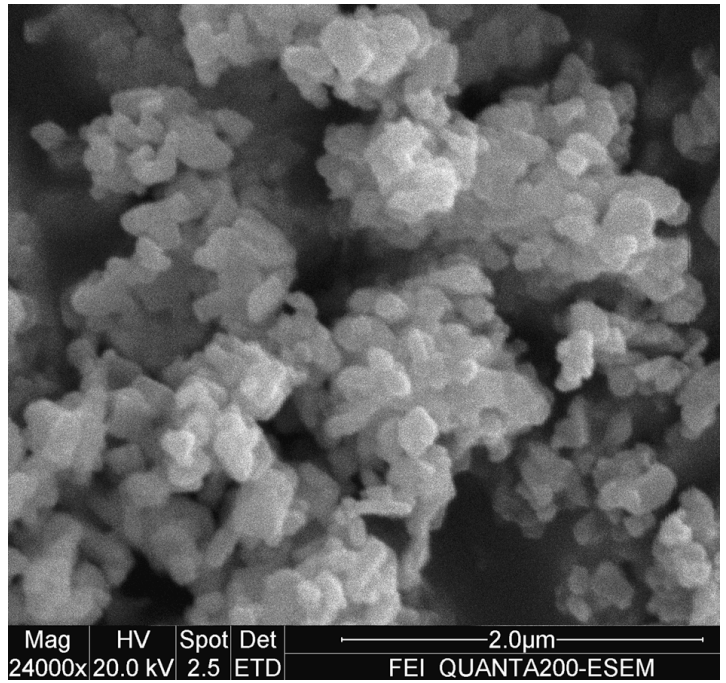

Figure 3. ESEM micrographs of nanocrystalline BTO calcined at $750^{\circ} \mathrm{C}$ for $5 \mathrm{~min}$

where $\theta$ is the diffraction angle, $\lambda$ the average wavelength of X-ray, $k$ the shape factor, and $\beta$ is taken as halfmaximum line breadth.

An increase in the grain size of BTO powder is observed as the annealing temperature increased up to 650 ${ }^{\circ} \mathrm{C}$ but decrease remarkably thereafter. Figure 3 shows the ESEM micrographs of bismuth titanate nanoparticles at temperature of $750^{\circ} \mathrm{C}$. The grain sizes estimated from SEM observations were different from those done by means of Schereer's equation. The Scherrer's equation assumes that all the crystallites are of the same size, but in an actual specimen, the size range and distribution affect $\beta$. Additionally, incoherent scattering from domains, distortions in the periodicity in the films, and micro-stress contribute to the line broadening and, hence, errors in the grain size estimation. Because the $\mathrm{X}$-ray line broadening yields relative crystallite size, if absolute sizes are necessary then electron microscopy must be used to establish a basis for comparison.

\subsection{Raman Spectra}

To further confirm the crystallization procedure of BTO in the MOD method, the powder precursors calcined at several temperatures were characterized using a Raman spectroscopy.

The Raman data on the powders calcined at $750^{\circ} \mathrm{C}$ shown in Figure 4(e) agreed with the published results [11], even though it is not quite exact for the mode counting in polycrystalline material due to possible symmetry breaking, low peak intensity and overlap of vibration modes. In accordance with Raman data of $\mathrm{Bi}_{4} \mathrm{Ti}_{3} \mathrm{O}_{12}$, $\mathrm{BaTiO}_{3}$, and $\mathrm{PbTiO}_{3}$ [11-13], a shorter bond length of Ti-O than that of Bi-O, suggests that the Raman phonon modes of the corresponding higher wavenumbers, such

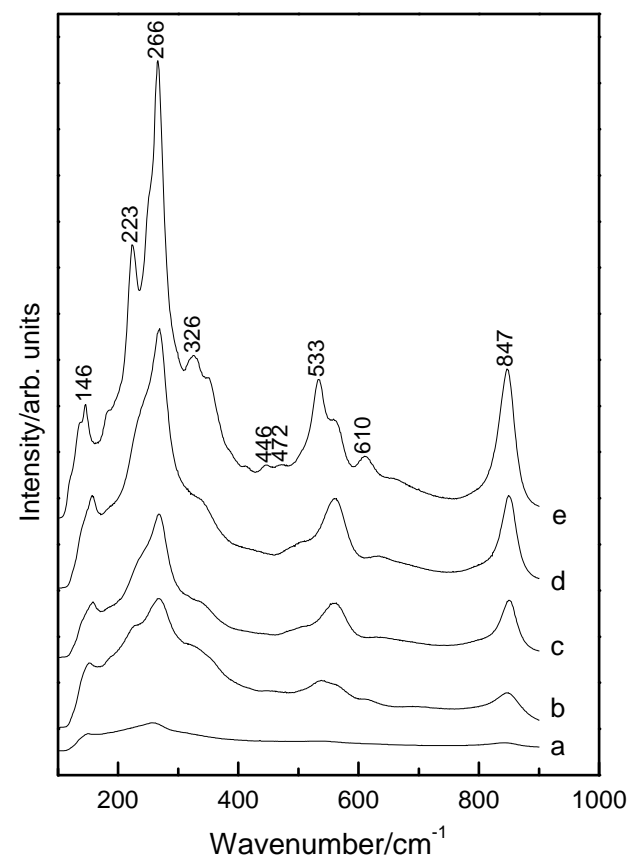

Figure 4. The evolution of the BTO Raman bands with temperature: (a) 90; (b) 450; (c) 550; (d) 650; and (e) $750^{\circ} \mathrm{C}$

as the modes at 610 and $847 \mathrm{~cm}^{-1}$, originated mainly from the vibrations of atoms inside the $\mathrm{TiO}_{6}$ octahedra. The eak at $847 \mathrm{~cm}^{-1}$ is attributed to the symmetric Ti-O stretching vibration, while the $610 \mathrm{~cm}^{-1}$ to asymmetric one; the 266 and $223 \mathrm{~cm}^{-1}$ modes are ascribed to the $\mathrm{O}$-Ti-O bending vibration. Although the mode at $223 \mathrm{~cm}^{-1}$ is Raman inactive according to the $O_{h}$ symmetry of $\mathrm{TiO}_{6}$, it is often observed because of the distortion of octahedron. The mode at $326 \mathrm{~cm}^{-1}$ is from a combination of the stretching and bending vibrations. The two modes at 533 $\mathrm{cm}^{-1}$ and $564 \mathrm{~cm}^{-1}$ correspond to the opposing excursions of the external apical oxygen atoms of the $\mathrm{TiO}_{6}$ octahedra. The $\mathrm{TiO}_{6}$ octahedra exhibit considerable distortion at room temperature so that some phonon modes, e.g., at 326, 533,610 , and $847 \mathrm{~cm}^{-1}$, appear wide and weak, which are expected to induce ferroelectric anomaly of BTO. The Raman modes of the corresponding lower wavenumbers, such as the mode at $117 \mathrm{~cm}^{-1}$, originated mainly from the vibrations between $\mathrm{Bi}$ and $\mathrm{O}$ atoms, which can be confirmed by the shift to higher wavenumber due to the modification of a lighter $\mathrm{Sm}$ atom at a Bi site with increasing doping concentration $[14,15]$.

In Raman spectra of powders calcined at $450-750^{\circ} \mathrm{C}$ for 5 min, Figure 4, a few extra peaks or shoulders not identified with BTO were detected at 152, 319 and 538 $\mathrm{cm}^{-1}$ at $450^{\circ} \mathrm{C}$, and 158,251 , and $326 \mathrm{~cm}^{-1}$ at $550^{\circ} \mathrm{C}$. In the samples annealed at $650^{\circ} \mathrm{C}$ three broad peaks at 339 , 501 and $635 \mathrm{~cm}^{-1}$ were observed.

From the above results, the following can be pointed 
out. 1) The sharp increase in the intensity of the $265 \mathrm{~cm}^{-1}$ band and the appearance of a band at $538 \mathrm{~cm}^{-1}$ along with three other peaks at 152,319 and $849 \mathrm{~cm}^{-1}$ in the sample calcined at $450^{\circ} \mathrm{C}$, indicated the rearrangement of a binary $\mathrm{Bi}_{2} \mathrm{O}_{3}-\mathrm{TiO}_{2}$ intermediate structure before the formation of BTO phase $[16,17]$. Such a binary intermediate phase, according to the X-ray diffraction results, seems to correspond to the $\mathrm{Bi}_{12} \mathrm{TiO}_{20}$ compound, albeit this is not clearly established. The Raman spectra are in agreement with the data reported in the literature within the experimental errors [11]. The major lines associated to crystalline $\mathrm{Bi}_{12} \mathrm{TiO}_{20}$ were identified in the sample. However, it has to emphasize that the data from the literature was obtained from Raman scattering using single crystals, and the measurements were performed in powdered polycrystalline samples. This could explain the large bandwidth and minor frequency-shift of the optical lines associated to polycrystalline samples. 2) Although the spectrum for the sample heated at $550^{\circ} \mathrm{C}$ was similar to that after $650^{\circ} \mathrm{C}$ except for the almost disappearance of the bands at $538 \mathrm{~cm}^{-1}$, but the appearance of a band at 158 and a shoulder at $515 \mathrm{~cm}^{-1}$ indicated the coexistence of the two $\mathrm{Bi}_{12} \mathrm{TiO}_{20}$ and $\mathrm{BTO}$ phases, which is in agreement with the DTA and X-ray diffraction results. 3) The complete disappearance of all the Raman bands corresponding to the intermediate phase and, on the other hand, the increase in the intensity of the peaks at 266, 533 and $847 \mathrm{~cm}^{-1}$, which are representative of a typical mixed-layered perovskite structure [17], indicated the formation of a not well crystallized BTO ternary phase close to the $\mathrm{Bi}_{4} \mathrm{Ti}_{3} \mathrm{O}_{12}$ composition.

From the above results, we can suggest that, in a first step, the formation of $\mathrm{Bi}_{12} \mathrm{TiO}_{20}$ particles might be consistent with an Avrami-type nucleation and growth mechanism [18], in which the particles continuously nucleated three-dimensionally within the amorphous polymeric precursor matrix below $550^{\circ} \mathrm{C}$. After the nucleus of crystal appears, the primary particle size gradually increases from the randomly distributed nuclei with the increasing temperature. The amount of the intermediate $\mathrm{Bi}_{12} \mathrm{TiO}_{20}$ phase rapidly decreased with the BTO formation and, finally, crystal growth of BTO by a solid-state reaction as the heat-treatment temperature increased takes place.

\subsection{FTIR Measurements}

The IR spectra of the initial and post-annealed powders of BTO are shown in Figure 5. After drying at $90^{\circ} \mathrm{C}$, the spectrum is complex due to the existence of lots of organic compounds. Band at $3500 \sim 3200 \mathrm{~cm}^{-1}$ is a characteristic group frequency from the stretch vibration of -OH [19]. The stretch $-\mathrm{CH}_{2}$ of located at $2930 \mathrm{~cm}^{-1}$. The broad band around $1750 \mathrm{~cm}^{-1}$ comes from $\mathrm{C}=\mathrm{O}$ stretch vibration. The peaks of 1385,1024 , and $731 \mathrm{~cm}^{-1}$ are the character

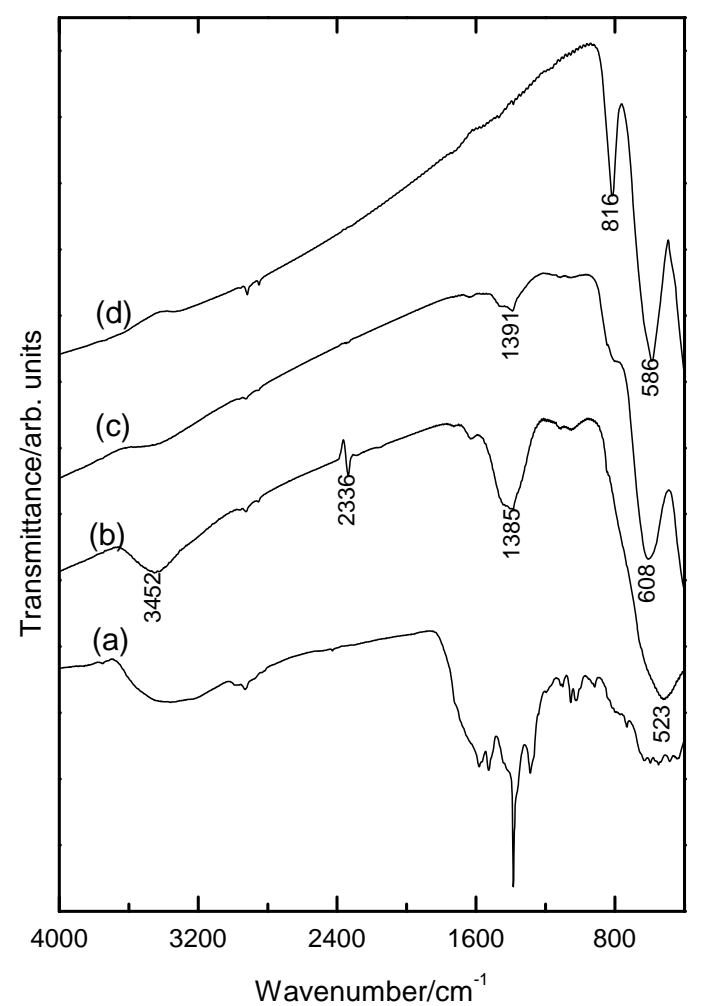

Figure 5. FTIR spectra of BTO precursor post-annealed at temperatures of 90 (a), 550 (b), 650 (c), and $750^{\circ} \mathrm{C}$ (d) for 5 min

istic ones of $\mathrm{NO}_{3}{ }^{-}$group. The band at $1285 \mathrm{~cm}^{-1}$ can be assigned to bending/stretching vibrations of $-\mathrm{COOH}$. The band at $1100 \mathrm{~cm}^{-1}$ is the stretching mode of C-O group, and the broad one around $700 \sim 400 \mathrm{~cm}^{-1}$ originates from the metal-oxygen (M-O) vibration. After annealing at $450^{\circ} \mathrm{C}$, many vibration lines disappear because of the evaporation of most solvents and decomposition of the organic ingredient. The strong and characteristic band of $1385 \mathrm{~cm}^{-1}$ is from the nitrate group. The peak at $2336 \mathrm{~cm}^{-1}$ is a characteristic pattern for the - $\mathrm{COOH}$ group. The only feature in spectra of 550 , and $650^{\circ} \mathrm{C}$ heated powders is the band at around $600 \mathrm{~cm}^{-1}$, originating from $\mathrm{M}-\mathrm{O}$ bonds. The IR results indicated that most decomposition could be achieved by heating above $650^{\circ} \mathrm{C}$.

\subsection{Reaction Mechanism}

In Bi-Ti solution system, $\mathrm{Ti}\left(\mathrm{OC}_{4} \mathrm{H}_{9}\right)_{4}$ reacts easily with $\mathrm{CH}_{3} \mathrm{COOH}$ to yield $\mathrm{Ti}\left(\mathrm{OC}_{4} \mathrm{H}_{9}\right)_{4-\mathrm{x}}\left(\mathrm{CH}_{3} \mathrm{COO}\right)_{\mathrm{x}}$ that has a very slow hydrolysis rate in a strong acidity solution:

$$
\begin{aligned}
\mathrm{Ti}\left(\mathrm{OC}_{4} \mathrm{H}_{9}\right)_{4}+\mathrm{xCH} 3 \mathrm{COOH} \\
\rightarrow \operatorname{Ti}\left(\mathrm{OC}_{4} \mathrm{H}_{9}\right)_{4-\mathrm{x}}\left(\mathrm{CH}_{3} \mathrm{COO}\right) \mathrm{x}+\mathrm{xC}_{4} \mathrm{H}_{9} \mathrm{OH}
\end{aligned}
$$

On the other hand, $\mathrm{H}^{+}$of acetic acid easily attacks alkoxy group $\left(-\mathrm{OC}_{4} \mathrm{H}_{9}\right)$ of $\mathrm{Ti}\left(\mathrm{OC}_{4} \mathrm{H}_{9}\right)_{4}$, which will expedite the hydrolysis reaction: 


$$
\begin{aligned}
& \left(-\mathrm{OC}_{4} \mathrm{H}_{9}\right) \text { of } \mathrm{Ti}\left(\mathrm{OC}_{4} \mathrm{H}_{9}\right)_{4} \text {, which } \\
& \equiv \mathrm{Ti}-\mathrm{OC}_{4} \mathrm{H}_{9}+\mathrm{H}^{+}+\mathrm{HOH} \rightarrow \\
& \equiv \mathrm{Ti}-\mathrm{OH}^{+} \mathrm{C}_{4} \mathrm{H}_{9}+\mathrm{HOH} \rightarrow \\
& \equiv \mathrm{Ti}-\mathrm{OH}+\mathrm{C}_{4} \mathrm{H}_{9} \mathrm{OH}+\mathrm{H}^{+} \\
& \equiv \mathrm{Ti}-\mathrm{OH}+\equiv \mathrm{Ti}-\mathrm{OC}_{4} \mathrm{H}_{9} \rightarrow \equiv \mathrm{Ti}-\mathrm{O}-\mathrm{Ti} \\
& \equiv \mathrm{Ti}-\mathrm{O}-\mathrm{Ti} \equiv+\equiv \mathrm{Ti}-\mathrm{OH} \rightarrow \\
& \equiv \mathrm{Ti}-\mathrm{O}-\mathrm{Ti}\left(\mathrm{OC}_{4} \mathrm{H}_{9}\right)_{2}-\mathrm{O}-\mathrm{Ti} \rightarrow \\
& \equiv \mathrm{Ti}-\mathrm{O}-\left[\mathrm{Ti}\left(\mathrm{OC}_{4} \mathrm{H}_{9}\right)_{2}\right] \mathrm{n}-\mathrm{O}-\mathrm{Ti} \equiv \\
& \mathrm{Bi}\left(\mathrm{NO}_{3}\right)_{3}+\mathrm{CH}_{3} \mathrm{OCH}_{2} \mathrm{CH}_{2} \mathrm{OH} \\
& \rightarrow \mathrm{CH}_{3} \mathrm{OCH}_{2} \mathrm{OB}\left(\mathrm{NO}_{3}\right)_{2}+\mathrm{HNO}_{3} \\
& \equiv \mathrm{Ti}\left(\mathrm{OC}_{4} \mathrm{H}_{9}\right)_{4}+\mathrm{CH}_{3} \mathrm{OCH}_{2} \mathrm{CH}_{2} \mathrm{OBi}\left(\mathrm{NO}_{3}\right)_{2} \rightarrow \\
& \mathrm{Ti}\left(\mathrm{OC}_{4} \mathrm{H}_{9}\right)_{3} \mathrm{OCH}_{2} \mathrm{CH}_{2} \mathrm{OBi}\left(\mathrm{NO}_{3}\right)_{2}+\mathrm{C}_{4} \mathrm{H}_{9} \mathrm{OCH}_{3}
\end{aligned}
$$

According to the above-mentioned analyses and the experimental results, the following reaction scheme is the most reasonable to describe the decomposition process:

$$
\begin{aligned}
& \mathrm{Ti}\left(\mathrm{OC}_{4} \mathrm{H}_{9}\right)_{3} \mathrm{OCH}_{2} \mathrm{CH}_{2} \mathrm{OBi}\left(\mathrm{NO}_{3}\right)_{2} \rightarrow \\
& \mathrm{Bi}_{2} \mathrm{O}_{3}+\mathrm{TiO}_{2}+\mathrm{CO}_{2} \uparrow+\mathrm{H}_{2} \mathrm{O}+\mathrm{NO}_{2} \uparrow
\end{aligned}
$$

Bismuth titanate $\mathrm{Bi}_{12} \mathrm{TiO}_{20}$ is crystallochemically related to $\gamma-\mathrm{Bi}_{2} \mathrm{O}_{3}$; these compounds have similar structural frameworks and almost identical cubic cell parameters [20]. In view of this fact, formation of $\mathrm{Bi}_{12} \mathrm{TiO}_{20}$ in the $\mathrm{Bi}_{2} \mathrm{O}_{3}-\mathrm{TiO}_{2}$ system can be considered as a phase transition from $\alpha-\mathrm{Bi}_{2} \mathrm{O}_{3}$ to $\gamma-\mathrm{Bi}_{2} \mathrm{O}_{3}$ initiated by incorporation of a titanium dioxide admixture into the $\mathrm{Bi}_{2} \mathrm{O}_{3}$ structure.

The solid-phase synthesis of $\mathrm{Bi}_{4} \mathrm{Ti}_{3} \mathrm{O}_{12}$ involves occurrence of both rearrangement and transport processes; thus, formation of $\mathrm{Bi}_{4} \mathrm{Ti}_{3} \mathrm{O}_{12}$ occurs by the mechanism of successive rearrangements:

$$
\begin{gathered}
\mathrm{Bi}_{2} \mathrm{O}_{3}+\mathrm{TiO}_{2} \rightarrow \mathrm{Bi}_{12} \mathrm{TiO}_{20} \\
\mathrm{Bi}_{12} \mathrm{TiO}_{20}+\mathrm{TiO}_{2} \rightarrow \mathrm{Bi}_{4} \mathrm{Ti}_{3} \mathrm{O}_{12}
\end{gathered}
$$

This transformation pattern reflects the crystallochemical genesis of the structure in the course of the solidphase reaction. The structure formation involves a successive increase in the number of the nearest atoms adjacent to $\mathrm{Bi}$, with the last, high-temperature stage being accompanied by a considerably larger change in the bismuth coordination number than the first, low-temperature stage [20].

\section{Conclusions}

In summary, homogeneous and fine BTO ceramic powders have been prepared by metalorgainc decomposition method. Based on TGA/DTA, and XRD results, we conclude that the synthesis of the BTO compound takes place through the formation of an intermediate phase of composition $\mathrm{Bi}_{12} \mathrm{TiO}_{20}$, which is formed during the heating between 350 and $550^{\circ} \mathrm{C}$. Prolonged heat treatment between 550 and $750^{\circ} \mathrm{C}$ promote a rapid consumption by solid-state reaction of the intermediate phase with the formation of BTO, without any indication on the formation of other different phases or segregation of the individual metal oxides. These results support the contention for the metalorganic precursor synthesis method as useful to prepare ceramics with complex composition such as those of bismuth titanates. The postulated mechanisms are further confirmed due to the structural variety as shown in Raman and FTIR studies.

\section{Acknowledgements}

This work is supported by the Youth Scientist Fund of Shandong Province (2007BS04007), the Doctoral Startup Foundation of Shandong Institute of Light Industry, and National Natural Science Foundation of China (50772 059).

\section{REFERENCES}

[1] P. Siriprapa, A. Watcharapasorn and S. Jiansirisomboon, "Electrical and Mechanical Characteristics of $\left(\mathrm{Bi}_{4-\mathrm{x}} \mathrm{La}_{\mathrm{x}}\right)$ $\mathrm{Ti}_{3} \mathrm{O}_{12}$ Ceramics," Ferroelectrics, Vol. 382, No. 1, 2009, pp. 160-165.

[2] I. L. Trubnikov, S. N. Svirskaya, A. A. Zubkov and I. N. Toguleva, "Possible Ways to Obtain Materials Based on Bismuth Titanate $\mathrm{Bi}_{4} \mathrm{Ti}_{3} \mathrm{O}_{12}$," Russian Journal of Applied Chemistry, Vol. 82, No. 11, 2009, pp. 1911-1914.

[3] A. Moure, A. Castro and L. Pardo, "Aurivillius-Type Ceramics, A Class of High Temperature Piezoelectric Materials: Drawbacks, Advantages and Trends," Progress in Solid State Chemistry, Vol. 37, No. 1, 2009, pp. 15-39.

[4] M. Villegas, A. C. Caballero, T. Jardiel, C. Arago and J. Maudes, "Evaluation of Piezoelectric Properties of $\mathrm{Bi}_{4} \mathrm{Ti}_{3} \mathrm{O}_{12}$ Based Ceramics at High Temperature," Ferroelectrics, Vol. 393, 2009, pp. 44-53.

[5] A. Watcharapasorn, P. Siriprapa, and S. Jiansirisomboon, "Grain Growth Behavior in Bismuth Titanate-Based Ceramics," Journal of the European Ceramic Society, Vol. 30, No. 1, 2010, pp. 87-93.

[6] P. Pookmanee and S. Phanichphant, "Characterization of Lead-Free Bismuth Titanate $\left(\mathrm{Bi}_{4} \mathrm{Ti}_{3} \mathrm{O}_{12}\right)$ Synthe-Sized by a Modified Oxalate Co-Precipitation Method," Journal of Ceramic Processing Research, Vol. 10, No. 4, 2009, pp. 448-452.

[7] H. Ke, W. Wang, L. Chen, J. Xu, D. Jia, Z. Lu and Y. Zhou, "Crystallization Process of Lanthanum-Substituted Bismuth Titanate Synthesized by a Facile Sol-Gel Method," Journal of Sol-Gel Science and Technology, Vol. 53, No. 1, 2010, pp. 135-140.

[8] Y. Wang, Y. Wen, H. Ding and Y. Shan, "Improved Structural Stability of Titanium-Doped Beta- $\mathrm{Bi}_{2} \mathrm{O}_{3}$ during 
Visible-Light-Activated Photocatalytic Processes," Journal of Materials Science, Vol. 45, No. 5, 2010, pp. 1385-1392.

[9] A. Watcharapasorn, P. Siriprapa and S. Jiansirisomboon, "Grain Growth Behavior in Bismuth Titanate-Based Ceramics," Journal of the European Ceramic Society, Vol. 30, No. 1, 2010, pp. 87-93.

[10] B. D. Stojanovic, A. Z. Simoes, C. O. Paiva-Santos, C. Quinelato, E. Longo and J. A. Varela, "Effect of Processing Route on the Phase Formation and Properties of $\mathrm{Bi}_{4} \mathrm{Ti}_{3} \mathrm{O}_{12}$ Ceramics," Ceramics International, Vol. 32, No. 6, 2006, pp. 707-712.

[11] H. Idink, V. Srikanth, W. B. White and E. C. Subbarao "Raman Study of Low Temperature Phase Transitions in Bismuth Titanate, $\mathrm{Bi}_{4} \mathrm{Ti}_{3} \mathrm{O}_{12}$," Journal of Applied Physics, Vol .76, No. 3, 1994, pp. 1819-1823.

[12] P. R. Graves, G. Hua, S. Myhra and J. G. Thompson, "The Raman Modes of the Aurivillius Phases: Temperature and Polarization Dependence," Journal of Solid State Chemistry, Vol. 114, No. 1, 1995, pp. 112-122.

[13] P. S. Dobal and R. S. Katiyar, "Studies on Ferroelectric Perovskites and Bi-Layered Compounds Using MicroRaman Spectroscopy," Journal of Raman Spectroscopy, Vol. 33, No. 6, 2002, pp. 405-423.

[14] W. L. Liu, H. R. Xia, H. Han and X. Q. Wang, "Structural and Electrical Characteristics of $\mathrm{Bi}_{3.5} \mathrm{SM}_{0.5} \mathrm{Ti}_{3} \mathrm{O}_{12}$ Thin Films on Si(100)," Journal of Crystal Growth, Vol. 264, No. 1-3, 2004, pp. 351-356.

[15] W. L. Liu, H. R. Xia, H. Han and X. Q. Wang, "Structural, Morphology and Electrical Studies of Sm-Modified Bismuth Titanate thin Films on Si(100)," Journal of Solid State Chemistry, Vol. 177, No. 9, 2004, pp. 3021-3027.

[16] J. F. Meng, P. S. Dobal, R. S. Katiyar and G. T. Zou, "Optical Phonon Modes and Phase Transition in the $\mathrm{Bi}_{4} \mathrm{Ge}_{3-\mathrm{X}} \mathrm{ti}_{\mathrm{x}} \mathrm{O}_{12}$ Ceramic System," Journal of Raman Spectroscopy, Vol. 29, No .12, 1998, pp. 1003-1008.

[17] J. Meng, R. S. Katiyar and G. T. Zou, "Micro-Raman Scattering of Bismuth Titanate at Low Temperature," Journal of Raman Spectroscopy, Vol. 28, No. 6, 1997, pp. 797-801.

[18] W. Li, J. Gu, J. Ma, X. M. Lu and J. S. Zhu, "Investigation on Effective Dimensionality of Domain Growth in $\mathrm{Bi}_{4} \mathrm{Ti}_{3} \mathrm{O}_{12}$ Films," Integrated Ferroelectrics, Vol. 79, No. 1, 2006, pp. 63-70.

[19] X. Jing, S. Chen and E. Yao, "Introduction of IR Spectra," Tianjian Technology Press, Tianjin, 1992, pp. 99-136.

[20] M. I. Morozov, L. P. Mezentseva and V. V. Gusarov, "Mechanism of Formation of $\mathrm{Bi}_{4} \mathrm{Ti}_{3} \mathrm{O}_{12}$," Russian Journal of General Chemistry, Vol. 72, No. 7, 2002, pp. 1038-1040. 